\title{
$\mathrm{Yb}_{2} \mathrm{O}_{3}-\mathrm{SiO}_{2}$ 系焼結助剤を用いたガス圧焼結 $\mathrm{Si}_{3} \mathrm{~N}_{4}$ の高温特性の $\mathrm{Yb}_{2} \mathrm{O}_{3} / \mathrm{SiO}_{2}$ モル比依存性
}

\author{
山本博一 ·秋山勝徳 $*$ 平田武彦** ·村上勇一郎* \\ 三菱重工業(株)長崎研究所, 851-0392 長崎市深堀町 5-717-1 \\ *三菱重工業(株)先進技術研究センター，236-8515 横浜市金沢区幸浦 1-8-1 \\ **三菱重工業(株)横浜研究所, 231-8715 横浜市中区錦町 12
}

\section{Dependence of $\mathrm{Yb}_{2} \mathrm{O}_{3} / \mathrm{SiO}_{2}$ Molar Ratio on High-Temperature Characteristics of Gas Pressure Sintered $\mathrm{Si}_{3} \mathrm{~N}_{4}$}

\author{
Hirokazu YAMAMOTO, Katsunori AKIYAMA, ${ }^{*}$ Takehiko HIRATA** and Yuichiro MURAKAMI* \\ Nagasaki Research and Develop Center, Mitsubishi Heavy Industries, Ltd., 5-717-1, Fukahori-cho, Nagasaki-shi $851-0392$ \\ *Advanced Technology Research Center, Mitsubishi Heavy Industries, Ltd., 1-8-1, Sachiura, Kanazawa-ku, Yokohama-shi 236-8515 \\ *** Yokohama Research and Development Center, Mitsubishi Heavy Industries, Ltd., 12, Nishiki-machi, Naka-ku, Yokohama-shi 231-8715
}

\begin{abstract}
High-temperature characteristics (especially high-temperature strength and oxidation resistance) of gas pressure sintered $\mathrm{Si}_{3} \mathrm{~N}_{4}$ ceramics using $\mathrm{Yb}_{2} \mathrm{O}_{3}-\mathrm{SiO}_{2}$ additives were evaluated. The high temperature characteristic of $\mathrm{Si}_{3} \mathrm{~N}_{4}$ depended on the $\mathrm{Yb}_{2} \mathrm{O}_{3} / \mathrm{SiO}_{2}$ molar ratio of additives. High $1500^{\circ} \mathrm{C}$ bending strength of $395 \mathrm{MPa}$ was obtained for sintered bodies with 10.0 mass $\%$ addition of additives with $\mathrm{Yb}_{2} \mathrm{O}_{3} / \mathrm{SiO}_{2}$ molar ratio of 1.0. Also, small weight change $\left(13.2 \mathrm{~g} / \mathrm{m}^{2}\right)$ during oxidation at $1300^{\circ} \mathrm{C}$ for $300 \mathrm{~h}$ was obtained in this sintered body. This is considered to be due to the precipitation of $\mathbf{Y b}_{4} \mathrm{Si}_{2} \mathbf{N}_{2} \mathbf{O}_{7}$ and $\mathbf{Y b}_{2} \mathrm{Si}_{2} \mathrm{O}_{7}$ phase in the grain boundary glass phase, as induced by a crystallization process.

[Received October 19, 2004; Accepted January 20, 2005]
\end{abstract}

Key-words : Silicon nitride, High-temperature strength, Grain-boundary phase

\section{1. 緒 言}

資源の乏しい我が国において省エネルギー化技術の開発は， 二酸化炭素排出量削減による地球環境保全のためにも緊急かつ 重要な課題である.この課題への対応策の一つとして, 窒化ケ イ素 $\left(\mathrm{Si}_{3} \mathrm{~N}_{4}\right)$ の優れた高温強さ, 破壊勒性, 耐熱衝撃性等を 活かし，各種高温機器へ適用することにより機器効率向上を図 る試みが多くなされている11.

$\mathrm{Si}_{3} \mathrm{~N}_{4}$ の高温強さを向上させる手法として，固相温度の高い ガラス相が粒界に生成する焼結助剂の適用，及び，粒界ガラ ス相の結晶化等が考えられている. $\mathrm{Si}_{3} \mathrm{~N}_{4}$ の粒界ガラス相を構 成すると考えられる多成分系の固相温度を表 $1^{2) \sim 6)}$ に示す。一 般的な $\mathrm{Si}_{3} \mathrm{~N}_{4}$ の焼結助剂である $\mathrm{Y}_{2} \mathrm{O}_{3}-\mathrm{Al}_{2} \mathrm{O}_{3}$ 系酸化物を用いた $\mathrm{Si}_{3} \mathrm{~N}_{4}$ の粒界に生成する $\mathrm{Y}_{2} \mathrm{O}_{3}-\mathrm{Al}_{2} \mathrm{O}_{3}-\mathrm{SiO}_{2}$ 系酸化物と比較して, $\mathrm{Yb}_{2} \mathrm{O}_{3}-\mathrm{SiO}_{2}$ 系酸化物の固相温度は $310 \mathrm{~K}$ 高い。この $\mathrm{Yb}_{2} \mathrm{O}_{3}-$ $\mathrm{SiO}_{2}$ 系酸化物を $\mathrm{Si}_{3} \mathrm{~N}_{4}$ の焼結助剤として用いることで高温特性 の向上が期待できる.

$\mathrm{Yb}_{2} \mathrm{O}_{3}-\mathrm{SiO}_{2}$ 系焼結助剤を用いた $\mathrm{Si}_{3} \mathrm{~N}_{4}$ に関して, $\mathrm{Yb}_{2} \mathrm{O}_{3}$ $\mathrm{SiO}_{2}-\mathrm{Si}_{3} \mathrm{~N}_{4}$ 系の $2023 \mathrm{~K}$ での固相の相関係を Nishimura と Mitomo $^{7)}$ が，この系の $1923 \mathrm{~K}$ での液相生成領域及び生成する ガラス相の特性を Murakami ら ${ }^{8)}$ が明らかにしている。この系

Table 1. Solidus Temperature of Various Ceramics

\begin{tabular}{c|c}
\hline Composition & Solidus Temperaturc (K) \\
\hline $\mathrm{Y}_{2} \mathrm{O}_{3}-\mathrm{Al}_{2} \mathrm{O}_{3}-\mathrm{SiO}_{2}{ }^{2)}$ & 1613 \\
$\mathrm{Yb}_{2} \mathrm{O}_{3}-\mathrm{Al}_{2} \mathrm{O}_{3}-\mathrm{SiO}_{2}{ }^{3)}$ & 1773 \\
$\mathrm{Er}_{2} \mathrm{Si}_{2} \mathrm{O}_{7}-\mathrm{Al}_{6} \mathrm{Si}_{2} \mathrm{O}_{13}-\mathrm{SiO}_{2}{ }^{3)}$ & 1713 \\
$\mathrm{Yb}_{2} \mathrm{O}_{3}-\mathrm{SiO}_{2}{ }^{4-6)}$ & 1923 \\
\hline
\end{tabular}

の化合物の中で $2153 \mathrm{~K}$ と高い融点を有し, 熱化学的特性が $\mathrm{Si}_{3} \mathrm{~N}_{4}$ に近い $\mathrm{Yb}_{4} \mathrm{Si}_{2} \mathrm{~N}_{2} \mathrm{O}_{7}$ に着目し, Nishimura ら ${ }^{9)}$ は, $\mathrm{Yb}_{2} \mathrm{O}_{3} /$ $\mathrm{SiO}_{2}$ モル比を 4 に固定した燒結助剂条件のホットプレス $\mathrm{Si}_{3} \mathrm{~N}_{4}$ が，粒界相に $\mathrm{Yb}_{4} \mathrm{Si}_{2} \mathrm{~N}_{2} \mathrm{O}_{7}$ が析出し $1500^{\circ} \mathrm{C}$ で $484 \mathrm{MPa}$ の高い高 温強さを有することを報告している. Park ら ${ }^{10)}$ は, $\mathrm{Yb}_{2} \mathrm{O}_{3}$ を 焼結助剤としたホットプレス $\mathrm{Si}_{3} \mathrm{~N}_{4}$ で粒界相への $\mathrm{Yb}_{4} \mathrm{Si}_{2} \mathrm{~N}_{2} \mathrm{O}_{7}$ の 析出を報告している. 更に, Guo ら ${ }^{11)}$ は, $\mathrm{Yb}_{2} \mathrm{O}_{3}-\mathrm{SiO}_{2}$ 系焼結 助剤を用いたホットプレス $\mathrm{Si}_{3} \mathrm{~N}_{4}$ の高温破壊特性の評価結果を 報告している. $\mathrm{Si}_{3} \mathrm{~N}_{4}-\mathrm{Yb}_{4} \mathrm{Si}_{2} \mathrm{~N}_{2} \mathrm{O}_{7}$ 組成の $\mathrm{Si}_{3} \mathrm{~N}_{4}$ に関しては多く の研究がなされているが， $\mathrm{Yb}_{2} \mathrm{O}_{3}-\mathrm{SiO}_{2}$ 系焼結助剤を用いた $\mathrm{Si}_{3} \mathrm{~N}_{4}$ の高温特性に及ぼす $\mathrm{Yb}_{2} \mathrm{O}_{3} / \mathrm{SiO}_{2}$ モル比の影響を検討した 例はない.

$\mathrm{Yb}_{2} \mathrm{O}_{3}-\mathrm{SiO}_{2}-\mathrm{Si}_{3} \mathrm{~N}_{4}$ 系の状態図 ${ }^{8)}$ より, 液相は $\mathrm{Yb}_{2} \mathrm{O}_{3} / \mathrm{SiO}_{2}$ モ ル比 $4\left(\mathrm{Yb}_{2} \mathrm{O}_{3} / \mathrm{SiO}_{2}\right.$ 重量比26.3) 以下の領域で生成するので, ガス圧焼結法により緻密な焼結体を得るための焼結助剂配合は $\mathrm{Yb}_{2} \mathrm{O}_{3} / \mathrm{SiO}_{2}$ モル比 4 以下と考えられる.

そこで, 本研究では, 無加圧焼結が可能となる液相生成領域 の $\mathrm{Yb}_{2} \mathrm{O}_{3} / \mathrm{SiO}_{2}$ モル比配合とした $\mathrm{Yb}_{2} \mathrm{O}_{3}-\mathrm{SiO}_{2}$ 系焼結助剂を用い た $\mathrm{Si}_{3} \mathrm{~N}_{4}$ の高温特性向上のための焼結助剤条件を明らかにする ことを目的として各種試験を実施した. 具体的には, 高融点酸 化物である $\mathrm{Yb}_{2} \mathrm{SiO}_{5}$ 及び $\mathrm{Yb}_{2} \mathrm{Si}_{2} \mathrm{O}_{7}$ を粒界相に析出させることに よる高温特性向上を狙い, $\mathrm{Yb}_{2} \mathrm{O}_{3} / \mathrm{SiO}_{2}$ モル比 1.0 以下で $\mathrm{Yb}_{2} \mathrm{O}_{3} /$ $\mathrm{SiO}_{2}$ モルを変化させた焼結助剂条件とし, 焼結後に粒界相結晶 化処理したガス圧焼結 $\mathrm{Si}_{3} \mathrm{~N}_{4}$ の作製及びその高温特性（高温強 さ及び耐酸化性）の評価を行い，ガス圧焼結法に適した焼結助 剂条件の検討を行った.

\section{2. 実験方法}

2.1 原料粉末及び配合組成

用いた原料粉末は, 宇部興産製 $\mathrm{Si}_{3} \mathrm{~N}_{4}$ 粉末 $\mathrm{SN}-\mathrm{E} 10$, 信越化学 


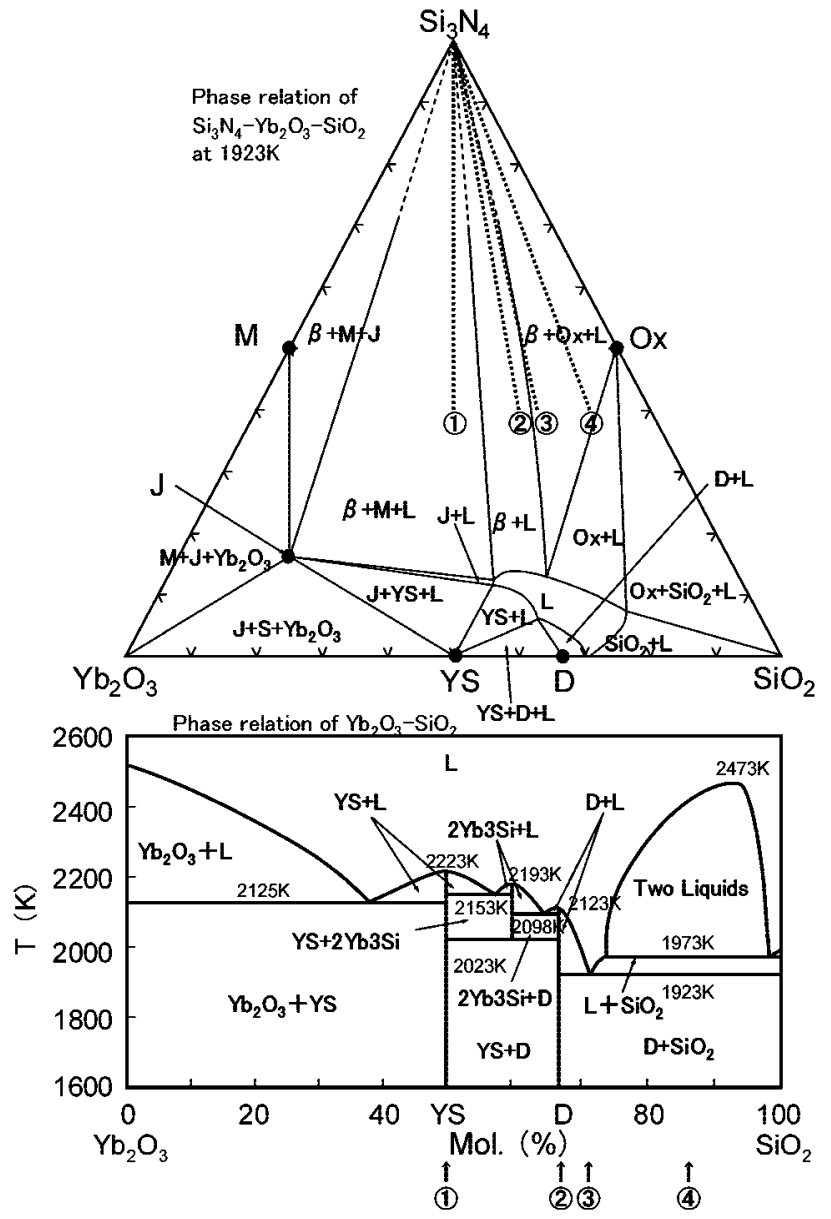

Fig. 1. Phase diagram of the $\mathrm{Yb}_{2} \mathrm{O}_{3}-\mathrm{SiO}_{2}-\mathrm{Si}_{3} \mathrm{~N}_{4}$ and $\mathrm{Yb}_{2} \mathrm{O}_{3}-\mathrm{SiO}_{2}$ system.

D: $\mathrm{Yb}_{2} \mathrm{Si}_{2} \mathrm{O}_{7}, \mathrm{~J}: \mathrm{Yb}_{4} \mathrm{Si}_{2} \mathrm{~N}_{2} \mathrm{O}_{7}, \mathrm{M}: \mathrm{Yb}_{2} \mathrm{Si}_{3} \mathrm{~N}_{4} \mathrm{O}_{3}, \mathrm{Ox}: \mathrm{Si}_{2} \mathrm{~N}_{2} \mathrm{O}$,

YS: $\mathrm{Yb}_{2} \mathrm{SiO}_{5}, 2 \mathrm{Yb} 3 \mathrm{Si}: \mathrm{Yb}_{4} \mathrm{Si}_{3} \mathrm{O}_{12}$

Additive: (1) $\mathrm{Yb} / \mathrm{Si} 1.0$ composition

(2) $\mathrm{Yb} / \mathrm{Si} 0.5$ composition

(3) $\mathrm{Yb} / \mathrm{Si} 0.4$ composition

(4) $\mathrm{Yb} / \mathrm{Si} 0.1$ composition

$\mathrm{Yb}_{2} \mathrm{O}_{3}$ 粉末 $\mathrm{SU}$, 新日鉄化学製 $\mathrm{SiO}_{2}$ 粉末エスクオーツ $\mathrm{M}-1$, で ある。

$\mathrm{Yb}_{2} \mathrm{O}_{3}$ を焼結助剂とした $\mathrm{Si}_{3} \mathrm{~N}_{4}$ の緻密化及び $\alpha-\beta$ 転移は， $\mathrm{Yb}_{2} \mathrm{O}_{3}-\mathrm{SiO}_{2}$ 系の共晶温度に対応する温度域から開始するとの報 告があることから ${ }^{10)}$, 焼結助剤の $\mathrm{Yb}_{2} \mathrm{O}_{3} / \mathrm{SiO}_{2}$ モル比は $\mathrm{Yb}_{2} \mathrm{O}_{3}$ -

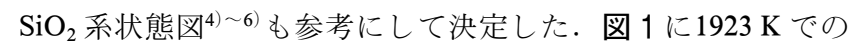
$\mathrm{Si}_{3} \mathrm{~N}_{4}-\mathrm{Yb}_{2} \mathrm{O}_{3}-\mathrm{SiO}_{2}$ 系状態図 ${ }^{8)}$ 及び $\mathrm{Yb}_{2} \mathrm{O}_{3}-\mathrm{SiO}_{2}$ 系状態図を示す. 焼結助剂配合として, (1) $\mathrm{Yb} / \mathrm{Si} 1.0$ 配合 $\left(\mathrm{Yb}_{2} \mathrm{O}_{3} / \mathrm{SiO}_{2}\right.$ モル比 1.0), (2) $\mathrm{Yb} / \mathrm{Si} 0.5$ 配合（同モル比0.5), (3) $\mathrm{Yb} / \mathrm{Si} 0.4$ 配合（同 モル比 0.408 ), (4) $\mathrm{Yb} / \mathrm{Si} 0.1$ 配合（同モル比 $0.163 ） の 4$ 配合を 選定した。この焼結助剂配合を図 1 の $\mathrm{Yb}_{2} \mathrm{O}_{3}-\mathrm{SiO}_{2}-\mathrm{Si}_{3} \mathrm{~N}_{4}$ 系状 態図上に点線で, $\mathrm{Yb}_{2} \mathrm{O}_{3}-\mathrm{SiO}_{2}$ 系状態図には矢印で示す.

(1) $\mathrm{Yb} / \mathrm{Si} 1.0$ 配合

$\mathrm{Yb}_{2} \mathrm{O}_{3} / \mathrm{SiO}_{2}$ モル比が1.0 $\left(\mathrm{Yb}_{2} \mathrm{O}_{3} / \mathrm{SiO}_{2}\right.$ 重量比6.57) の配合で ある. $\mathrm{Yb}_{2} \mathrm{O}_{3}-\mathrm{SiO}_{2}-\mathrm{Si}_{3} \mathrm{~N}_{4}$ 系状態図より $1923 \mathrm{~K}$ では $\mathrm{Si}_{3} \mathrm{~N}_{4}, \mathrm{Yb}_{2}$ $\mathrm{Si}_{3} \mathrm{~N}_{4} \mathrm{O}_{3}$ 及び液相が共存し, $\mathrm{Yb}_{2} \mathrm{O}_{3}-\mathrm{SiO}_{2}$ 系で最も融点が高く $(2223 \mathrm{~K})$, かつ固相温度も $2125 \mathrm{~K} \sim 2153 \mathrm{~K}$ と高く, 優れた高温 特性が期待できる配合である。
Table 2. Composition of $\mathrm{Si}_{3} \mathrm{~N}_{4}$ Raw Powder

\begin{tabular}{lcccc}
\hline \multirow{2}{*}{ Additive } & \multicolumn{3}{c}{ Composition (mass\%) } & \multirow{2}{*}{$\begin{array}{c}\text { Sintering } \\
\text { additive(mass\%) }\end{array}$} \\
\cline { 2 - 4 } & $\mathrm{Yb}_{2} \mathrm{O}_{3}$ & $\mathrm{SiO}_{2}$ & $\mathrm{Si}_{3} \mathrm{~N}_{4}$ & adin \\
\hline \hline \multirow{2}{*}{ (1) $\mathrm{Yb} / \mathrm{Si1.0}$} & 8.53 & 1.30 & 90.0 & 10.0 \\
& 17.36 & 2.64 & 80.0 & 20.0 \\
& 26.04 & 3.96 & 70.0 & 30.0 \\
& 34.72 & 5.28 & 60.0 & 40.0 \\
\hline (2) $\mathrm{Yb} / \mathrm{SiO} .5$ & 7.66 & 2.34 & 90.0 & 10.0 \\
\hline (3) $\mathrm{Yb} / \mathrm{SiO} .4$ & 7.31 & 2.69 & 90.0 & 10.0 \\
\hline \multirow{2}{*}{ (4) $\mathrm{Yb} / \mathrm{SiO} 0.1$} & 5.17 & 4.83 & 90.0 & 10.0 \\
& 15.5 & 14.5 & 70.0 & 30.0 \\
\hline
\end{tabular}

(2) $\mathrm{Yb} / \mathrm{Si} 0.5$ 配合

$\mathrm{Yb}_{2} \mathrm{O}_{3} / \mathrm{SiO}_{2}$ モル比が0.5 $\left(\mathrm{Yb}_{2} \mathrm{O}_{3} / \mathrm{SiO}_{2}\right.$ 重量比3.27) で, $\mathrm{Yb}_{2} \mathrm{O}_{3}$ $\mathrm{SiO}_{2}-\mathrm{Si}_{3} \mathrm{~N}_{4}$ 系状態図より $1923 \mathrm{~K}$ では $\mathrm{Si}_{3} \mathrm{~N}_{4}$ と液相が共存し, 焼 結の容易性と優れた高温特性が期待できる配合である.

(3) $\mathrm{Yb} / \mathrm{Si} 0.4$ 配合

$\mathrm{Yb}_{2} \mathrm{O}_{3} / \mathrm{SiO}_{2}$ モル比が0.408 $\left(\mathrm{Yb}_{2} \mathrm{O}_{3} / \mathrm{SiO}_{2}\right.$ 重量比2.71) である. $\mathrm{Yb}_{2} \mathrm{O}_{3}-\mathrm{SiO}_{2}-\mathrm{Si}_{3} \mathrm{~N}_{4}$ 系状態図より $1923 \mathrm{~K}$ では $\mathrm{Si}_{3} \mathrm{~N}_{4}$ と液相が共存 し, $\mathrm{Yb}_{2} \mathrm{O}_{3}-\mathrm{SiO}_{2}$ 系の共晶組成と同じモル比を持つ配合で, 焼結 性に優れると考えられる.

(4) $\mathrm{Yb} / \mathrm{Si} 0.1$ 配合

$\mathrm{Yb}_{2} \mathrm{O}_{3} / \mathrm{SiO}_{2}$ モル比が $0.163\left(\mathrm{Yb}_{2} \mathrm{O}_{3} / \mathrm{SiO}_{2}\right.$ 重量比 1.07) で, $\mathrm{Yb}_{2} \mathrm{O}_{3}-\mathrm{SiO}_{2}-\mathrm{Si}_{3} \mathrm{~N}_{4}$ 系状態図より $1923 \mathrm{~K}$ では $\mathrm{Si}_{3} \mathrm{~N}_{4}, \mathrm{Si}_{2} \mathrm{~N}_{2} \mathrm{O}$ 及び 液相が共存する配合である。また, $\mathrm{Yb}_{2} \mathrm{O}_{3}-\mathrm{SiO}_{2}$ 系では 2 種類 の液相が共存する不混和液相領域が存在し, 液相温度が最も低 く焼結性に優れると考えられる.

焼結助剤配合を(1)〜 (4)の4 種類とし，焼結助剂添加量 10 mass\%を基準とし，一部40 mass\%まで添加量を変化させてガ 又圧焼結試験を行った。これらの各試料の原料配合を表 2 に示 す.なお, $\mathrm{Si}_{3} \mathrm{~N}_{4}$ 粉末に含まれる不純物 $\mathrm{SiO}_{2}$ 量を定量化した結 果, 不純物 $\mathrm{SiO}_{2}$ 量は2.12 mass\%であったので, この值を基に 添加する $\mathrm{SiO}_{2}$ 量を決定した.

\section{2 焼結体の作製・評価}

各原料粉末を所定量秤量後, 分散媒の 1-ブタノールにポリエ チレンアミン系高分子剤の分散剂とともに添加し, ボールミル による湿式混合法で約 $170 \mathrm{~h}$ 分散・混合後, ロータリーエバポ レーターを用いて乾燥し, 混合粉末を得た. 混合粉末を乳鉢で 解砕後, 90 メッシュのふるいを通し, 圧力 $39.2 \mathrm{MPa}$ で一軸成 形後, 圧力 $392 \mathrm{MPa}$ の条件で冷間等方圧成形を行い, $\phi 60 \mathrm{~mm}$ $\times 6 \mathrm{mmt}$ の円盤状の成形体を得た。成形体を窒素ガス圧 0.58 $\mathrm{MPa}$ の䨌囲気下, 焼結温度 $1800 \sim 2000^{\circ} \mathrm{C}$ で $4 \mathrm{~h}$ 保持の条件でガ ス圧焼結を行った，焼結終了後に炉冷することなく，Yb-SiO-N 系のガラスの特性評価結果から明らかになっているガラ 又相の結晶化開始温度 ${ }^{8)}$ をと, 結晶核生成処理として $950^{\circ} \mathrm{C}$ で10 min 保持, その後結晶核成長熱処理として $1200^{\circ} \mathrm{C} て ゙ ~ 4 \mathrm{~h}$ 保 持する粒界相結晶化熱処理を, すべての試料について行った.

焼結体の評価は, アルキメデス法によるかさ密度測定, 光学 顕微鏡による組織観察, X 線回折法 XRD による生成相の同定 を行った．曲げ強さは JIS R1601 に準拠した試験片を用い，大 気中で室温, $1300^{\circ} \mathrm{C}, 1400^{\circ} \mathrm{C}$ 及び $1500^{\circ} \mathrm{C}$ の各温度で 4 点曲げ強 さ試験を行った。耐酸化性の評価は, JIS R1601 に準拠した試 験片を大気中, $1300^{\circ} \mathrm{C} て ゙ 300 \mathrm{~h}$ 保持した後の重量変化により評 価した. 


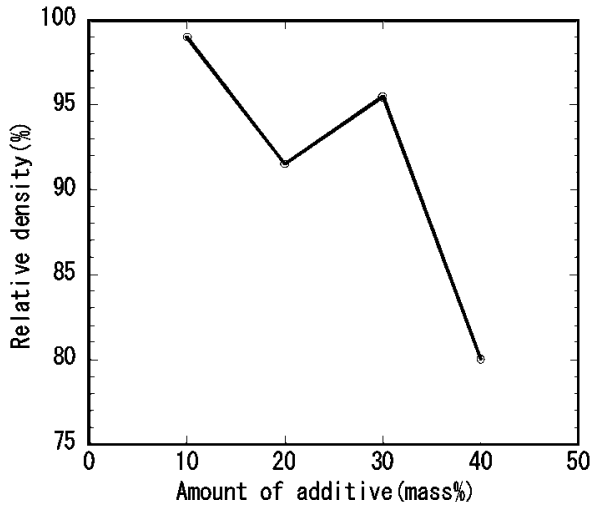

Fig. 2. Amount of additive dependence of relative density. (Additive: (1) Yb/Si 1.0 composition)

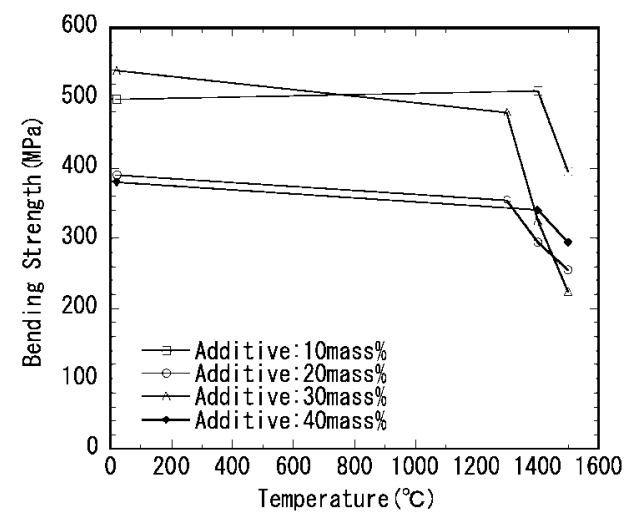

Fig. 3. Temperature dependence of the bending strength. (Additive: (1) $\mathrm{Yb} / \mathrm{Si} 1.0$ composition)

\section{3. 結果及び考察}

\section{1 高温特性評価}

\subsection{1 高温強さ評価}

(1) $\mathrm{Yb} / \mathrm{Si} 1.0$ 配合

焼結助剂添加量 10 mass\%で，1800～ $2000^{\circ} \mathrm{C}$ の温度で焼結し た $\mathrm{Si}_{3} \mathrm{~N}_{4}$ の光学顕微鏡による気孔分布観察を行った.この組成 は $\mathrm{Yb}_{2} \mathrm{O}_{3}-\mathrm{SiO}_{2}$ 系での固相温度が高いため $\mathrm{Si}_{3} \mathrm{~N}_{4}$ の焼結性が低 下し, $1800^{\circ} \mathrm{C}$ で焼結した $\mathrm{Si}_{3} \mathrm{~N}_{4}$ には多数の気孔が残存していた. $2000^{\circ} \mathrm{C}$ で焼結した $\mathrm{Si}_{3} \mathrm{~N}_{4}$ では，1800〜 $1900^{\circ} \mathrm{C}$ で焼結した $\mathrm{Si}_{3} \mathrm{~N}_{4}$ と比較して気孔量の減少が認められたので, 焼結温度を $2000^{\circ} \mathrm{C}$ とした。焼結助剤添加量を 10〜 40 mass\% と变化させた条件で 焼結した $\mathrm{Si}_{3} \mathrm{~N}_{4}$ の相対密度の焼結助剤添加量依存性を図 2 に示 す. 焼結助剤添加量 10 mass $\%$ の条件で相対密度が $99.0 \%$ と最も 緻密化し, 焼結助剂添加量 30 mass\%で少し高い相対密度とな るが, 焼結助剤添加量が増すに従って相対密度が低下する傾向 が認められた。

曲げ強さの温度依存性評価結果を図 3 に示す。焼結助剂添加 量 10 mass \%とした $\mathrm{Si}_{3} \mathrm{~N}_{4}$ は，室温の曲げ強さが $498 \mathrm{MPa}, 1400$ ${ }^{\circ} \mathrm{C}$ の曲げ強さが $510 \mathrm{MPa}$ と強さの低下は認められない. $1500^{\circ} \mathrm{C}$ では曲げ強さが $395 \mathrm{MPa}$ と若干低下するが，1500Cにおいても 高い高温強さを有することが明らかとなった，室温強さは相対 密度の焼結助剂添加量依存性の傾向と一致して, 焼結助剂添加 量 30 mass\%の $\mathrm{Si}_{3} \mathrm{~N}_{4}$ が $540 \mathrm{MPa}$ と高い值となったが，焼結助剂 添加量が20, 40 mass\%の $\mathrm{Si}_{3} \mathrm{~N}_{4}$ では, 室温強さが $390 \mathrm{MPa}$ 程度

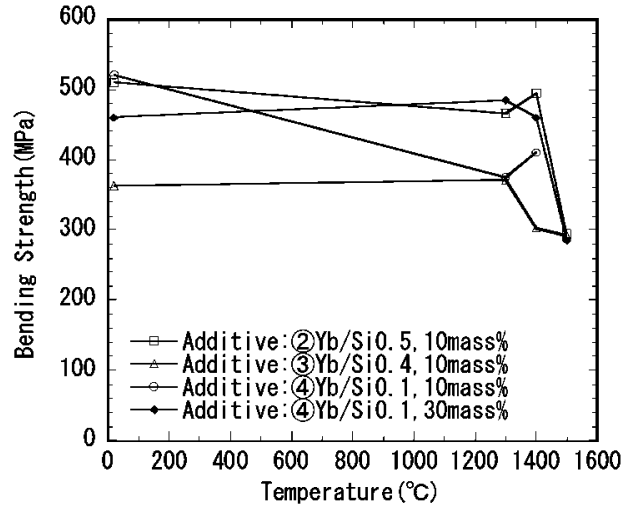

Fig. 4. Temperature dependence of the bending strength. (Additive: (2) $\mathrm{Yb} / \mathrm{Si} 0.5$ composition

(3) $\mathrm{Yb} / \mathrm{Si} 0.4$ composition

(4) $\mathrm{Yb} / \mathrm{Si} 0.1$ composition)

の低い值であった、焼結助剤添加量が 20 mass\%以上の $\mathrm{Si}_{3} \mathrm{~N}_{4}$ の $1400^{\circ} \mathrm{C}$ での曲げ強さは $295 \sim 340 \mathrm{MPa}$ 程度の低い值であった.

(2) $\mathrm{Yb} / \mathrm{Si} 0.5$ 配合

この焼結助剤を用いて焼結した $\mathrm{Si}_{3} \mathrm{~N}_{4}$ の光学顕微鏡による組 織観察を行った結果，高い焼結温度で焼結を行った $\mathrm{Si}_{3} \mathrm{~N}_{4}$ には 異常粒成長が認められた。そこで, (1) Yb/Si 1.0配合と比較し て低い焼結温度で焼結を行った。この結果, 焼結助剤添加量 10 mass $\% ， 1850^{\circ} \mathrm{C}$ で焼結した $\mathrm{Si}_{3} \mathrm{~N}_{4}$ が，相対密度 $98.5 \%$ と最も緻 密化した.

この条件の $\mathrm{Si}_{3} \mathrm{~N}_{4}$ の曲げ強さの温度依存性を図 4 に示す．室 温で $510 \mathrm{MPa}, 1400^{\circ} \mathrm{C}$ で $495 \mathrm{MPa}$ と $1400^{\circ} \mathrm{C}$ ま゙は曲げ強さを維 持するが， $1500^{\circ} \mathrm{C} て ゙$ 曲げ強さ $295 \mathrm{MPa}$ と急激に強さが低下した. (3) $\mathrm{Yb} / \mathrm{Si} 0.4$ 配合

この配合は $\mathrm{Yb}_{2} \mathrm{O}_{3}-\mathrm{SiO}_{2}$ 系での固相温度が低いため低温での 焼結が可能であり, 焼結助剤添加量 10 mass \%の条件で焼結温 度 $1800^{\circ} \mathrm{C}$ とした $\mathrm{Si}_{3} \mathrm{~N}_{4}$ は相対密度が $99.7 \%$ まで緻密化した。

この $\mathrm{Si}_{3} \mathrm{~N}_{4}$ の曲げ強さの温度依存性を図 4 に示すが，ほぼ理 論密度まで緻密化しているにもかかわらず，室温強度さが 363 $\mathrm{MPa}$ と低い結果となった. 更に, $1400^{\circ} \mathrm{C} て ゙ 302 \mathrm{MPa}, 1500^{\circ} \mathrm{C}$ で $292 \mathrm{MPa}$ と低い曲げ強さであった.

(4) $\mathrm{Yb} / \mathrm{Si} 0.1$ 配合

$\mathrm{Yb}_{2} \mathrm{O}_{3}-\mathrm{SiO}_{2}$ 系で不混和液相が存在する配合で, 液相の種類 により $\mathrm{Si}_{3} \mathrm{~N}_{4}$ の液相への溶解度や粘度等の特性が異なるため, $\alpha-\beta$ 転移や焼結挙動はより複雑になると考えられる。

焼結助剂量を 10 mass $\%, 30$ mass \% とした $\mathrm{Si}_{3} \mathrm{~N}_{4}$ を作製し, 光学顕微鏡による気孔分布観察を行った. この結果, 微細な気 孔が残存する組織であるが，焼結温度を $2000^{\circ} \mathrm{C}$ とした $\mathrm{Si}_{3} \mathrm{~N}_{4}$ は, $1900^{\circ} \mathrm{C}$ で焼結したものと比較して微細な気孔が消失する傾 向が認められた. 相対密度は両者とも $99.0 \%$ と十分に緻密化し たので, 焼結温度を $2000^{\circ} \mathrm{C}$ した $\mathrm{Si}_{3} \mathrm{~N}_{4}$ の評価を行った。

曲げ強さの温度依存性を図 4 に示すが，室温強さは 460～520 $\mathrm{MPa}$ と(1) $\mathrm{Yb} / \mathrm{Si}$ 1.0配合の $\mathrm{Si}_{3} \mathrm{~N}_{4}$ と同程度の值であった。しか し, 高温強さは, 焼結助剤添加量 10 mass $\%$ の $\mathrm{Si}_{3} \mathrm{~N}_{4}$ は $1300^{\circ} \mathrm{C}$ で 曲げ強さが $375 \mathrm{MPa}$ と低下した。焼結助剤添加量 30 mass $\%$ の $\mathrm{Si}_{3} \mathrm{~N}_{4}$ では $1400^{\circ} \mathrm{C}$ あで $450 \mathrm{MPa}$ 程度の強さを保持するが， 1500 ${ }^{\circ} \mathrm{C} て ゙ は 285 \mathrm{MPa}$ と曲げ強さが低下した.

\section{1 .2 耐酸化性評価}

各焼結助剤系で焼結助剤添加量を 10 mass\%とした $\mathrm{Si}_{3} \mathrm{~N}_{4}$ を， $1300^{\circ} \mathrm{C}$ で $300 \mathrm{~h}$ 大気中に保持する条件で酸化増量を測定した結 
Table 3. Weight Change of $\mathrm{Si}_{3} \mathrm{~N}_{4}$ Ceramics after Oxidation at $1300^{\circ} \mathrm{C}$

\begin{tabular}{|c|c|c|c|c|}
\hline \multirow{2}{*}{ Additive } & \multicolumn{3}{|c|}{ Cormposition (nass $\%$ ) } & \multirow{2}{*}{$\begin{array}{c}\text { Weight change } \\
\text { during oxidation } \\
\left(\mathrm{g} / \mathrm{m}^{2}\right)\end{array}$} \\
\hline & $\mathrm{Yb}_{2} \mathrm{O}_{3}$ & $\mathrm{SiO}_{2}$ & $\mathrm{Si}_{3} \mathrm{~N}_{4}$ & \\
\hline (1) $\mathrm{Yb} / \operatorname{sil} 1.0$ & 8.53 & 1.30 & 90.0 & 13.2 \\
\hline (2) $\mathrm{Yb} / \mathrm{Si0} .5$ & 7.66 & 2.34 & 90.0 & 28.1 \\
\hline (4) $\mathrm{Yb} / 5 \mathrm{iO} . \mathrm{l}$ & 5.17 & 4.83 & 90.0 & 25.8 \\
\hline
\end{tabular}

Table 4. Phase of $\mathrm{Si}_{3} \mathrm{~N}_{4}$ Ceramics Detected by XRD

\begin{tabular}{|c|c|c|c|c|c|}
\hline \multirow{2}{*}{ Additive } & \multicolumn{3}{|c|}{ Composition (massw) } & \multirow{2}{*}{$\begin{array}{c}\text { Phase detected } \\
\text { by XRD }\end{array}$} & \multirow{2}{*}{$\begin{array}{l}\text { Precipitated phase } \\
\text { assumed from phase diagram }\end{array}$} \\
\hline & $\mathrm{Yb}_{2} \mathrm{O}_{3}$ & $\mathrm{SiO}_{2}$ & $\mathrm{Si}_{3} \mathrm{Y}_{4}$ & & \\
\hline \multirow{3}{*}{ (1)Yb/Sil.o } & \multirow{3}{*}{ 8. 53} & \multirow{3}{*}{1.30} & \multirow{3}{*}{90.0} & $\beta-\mathrm{Si}_{3} \mathrm{~N}_{4}$ & \multirow{3}{*}{$\mathrm{Yb}_{2} \mathrm{SiO}_{5}$} \\
\hline & & & & $\mathrm{Yb}_{2} \mathrm{Si}_{2} \mathrm{O}_{7}$ & \\
\hline & & & & $\mathrm{Yb}_{4} \mathrm{Si}_{2} \mathrm{~T}_{2} \mathrm{O}_{\mathrm{T}}$ & \\
\hline \multirow{2}{*}{ (2) $\mathrm{Yb} / \mathrm{si} 0.5$} & \multirow{2}{*}{ 7. 66} & \multirow{2}{*}{2.34} & \multirow{2}{*}{90.0} & $\beta-\mathrm{Si}_{3} \mathrm{~N}_{4}$ & \multirow{2}{*}{$\mathrm{Yb}_{2} \mathrm{Si}_{2} \mathrm{O}_{7}$} \\
\hline & & & & $\mathrm{Yb}_{5} \mathrm{Si}_{2} \mathrm{Y}_{2} \mathrm{O}_{7}$ & \\
\hline \multirow{2}{*}{ (3) $\mathrm{Yb} / \mathrm{Si} 0.4$} & \multirow{2}{*}{ 7. 31} & \multirow{2}{*}{2.69} & \multirow{2}{*}{90.0} & \multirow{2}{*}{$\beta-\mathrm{Si}_{3} \mathrm{~N}_{4}$} & $\mathrm{Yb}_{2}, \mathrm{Si}_{2} \mathrm{O}_{7}$ \\
\hline & & & & & $\mathrm{Si}_{2} \mathrm{~N}_{2} \mathrm{O}$ \\
\hline \multirow{2}{*}{ (4) $\mathrm{rb} / \mathrm{siO} 0.1$} & \multirow{2}{*}{ 5. 17} & \multirow{2}{*}{ 4. 83} & \multirow{2}{*}{90.0} & \multirow{2}{*}{$\beta-\mathrm{Si}_{3} \mathrm{~N}_{4}$} & $\mathrm{Yb}_{2} \mathrm{Si}_{2} \mathrm{O}_{7}$ \\
\hline & & & & & $\mathrm{Si}_{2} \mathrm{~N}_{2} \mathrm{O}$ \\
\hline
\end{tabular}

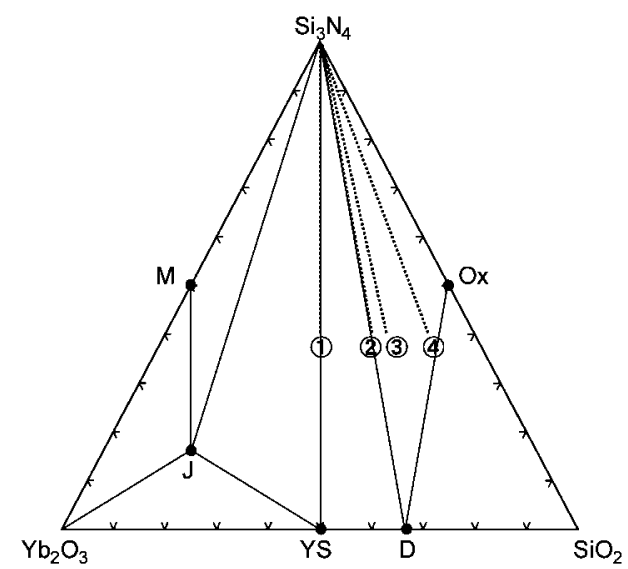

Fig. 5. Phase relation of $\mathrm{Yb}_{2} \mathrm{O}_{3}-\mathrm{SiO}_{2}-\mathrm{Si}_{3} \mathrm{~N}_{4}$ system. D: $\mathrm{Yb}_{2} \mathrm{Si}_{2} \mathrm{O}_{7}, \mathrm{~J}: \mathrm{Yb}_{4} \mathrm{Si}_{2} \mathrm{~N}_{2} \mathrm{O}_{7}, \mathrm{M}: \mathrm{Yb}_{2} \mathrm{Si}_{3} \mathrm{~N}_{4} \mathrm{O}_{3}, \mathrm{Ox}: \mathrm{Si}_{2} \mathrm{~N}_{2} \mathrm{O}$, YS: $\mathrm{Yb}_{2} \mathrm{SiO}_{5}$

Additive: (1) $\mathrm{Yb} / \mathrm{Si} 1.0$ composition

(2) $\mathrm{Yb} / \mathrm{Si} 0.5$ composition

(3) $\mathrm{Yb} / \mathrm{Si} 0.4$ composition

(4) $\mathrm{Yb} / \mathrm{Si} 0.1$ composition

果を表 3 に示す。なお, (3) Yb/Si 0.4配合の試料は緻密化して いるが，室温強さが低いため耐酸化試験は実施しなかった。

(1) $\mathrm{Yb} / \mathrm{Si} 1.0$ 配合の試料は, 酸化増量が $13.2 \mathrm{~g} / \mathrm{m}^{2}$ と優れた耐 酸化性を示した. (2) $\mathrm{Yb} / \mathrm{Si}$ 0.5配合の $\mathrm{Si}_{3} \mathrm{~N}_{4}$ は相対密度が $98.5 \%$ までしか緻密化していないため, 酸化増量は $28.1 \mathrm{~g} / \mathrm{m}^{2}$ とかな り大きい值となった. (4) $\mathrm{Yb} / \mathrm{Si} 0.1$ 配合の $\mathrm{Si}_{3} \mathrm{~N}_{4}$ は, 相対密度が 99.0\%まで緻密化しているにもかかわらず, 酸化増量は $25.8 \mathrm{~g} /$ $\mathrm{m}^{2}$ と (1) $\mathrm{Yb} / \mathrm{Si} 1.0$ 配合の $\mathrm{Si}_{3} \mathrm{~N}_{4}$ と比較すると, 耐酸化性に劣る 結果となった.

\section{2 粒界析出結晶相と高温特性の関係}

各焼結助剂配合で，焼結助剤添加量 10 mass\%とした $\mathrm{Si}_{3} \mathrm{~N}_{4}$ の 生成相をXRD により同定した結果を表 4 に示す。粒界相の結 晶化処理により析出する結晶相を検討するために, 結晶化処理 温度に近い温度である $1523 \mathrm{~K}$ での $\mathrm{Yb}_{2} \mathrm{O}_{3}-\mathrm{SiO}_{2}-\mathrm{Si}_{3} \mathrm{~N}_{4}$ 系状態図 を作成した。この結果を図 5 に示すが，Nishimura と $\mathrm{Mitomo}^{7)}$
Table 5. Properties of $\mathrm{Si}_{3} \mathrm{~N}_{4}$ Ceramics

\begin{tabular}{|c|c|c|c|c|c|c|}
\hline \multirow{2}{*}{ Additive } & \multirow{2}{*}{$\begin{array}{c}\text { Phase detected } \\
\text { by XRD }\end{array}$} & \multicolumn{4}{|c|}{ Bending Strength (MF'a) } & \multirow{2}{*}{$\begin{array}{l}\text { Weight change } \\
\text { during oxidation } \\
\left(\mathrm{g} / \mathrm{m}^{2}\right)\end{array}$} \\
\hline & & R. T. & $1300^{\circ} \mathrm{C}$ & $1400^{\circ} \mathrm{C}$ & $1500^{\circ} \mathrm{C}$ & \\
\hline (1) $\mathrm{Yb} / \mathrm{Sil} .0$ & $\begin{array}{c}\beta-\mathrm{Si}_{3} \mathrm{~N}_{4} \\
\mathrm{Yb}_{2} \mathrm{Si}_{2} \mathrm{O}_{7}, \mathrm{Yb}_{4} \mathrm{Si}_{2} \mathrm{~N}_{2} \mathrm{O}_{7}\end{array}$ & 498 & - & 510 & 395 & 13. 2 \\
\hline (2) $\mathrm{Yb} / \mathrm{Si0} .5$ & $B-\mathrm{Si}_{3} \mathrm{~N}_{4}, \mathrm{Yb}_{4}, \mathrm{Si}_{2} \mathrm{~N}_{2} \mathrm{O}_{7}$ & 510 & - & 495 & 295 & 28.1 \\
\hline (3) $\mathrm{Yb} / \mathrm{Si} 0.4$ & $\beta-\mathrm{Si}_{3} \mathrm{~N}_{4}$ & 363 & 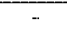 & 302 & 292 & - \\
\hline (4) $\mathrm{Yb} / \mathrm{Si} 0.1$ & $\beta-\mathrm{Si}_{3} \mathrm{~N}_{4}$ & 520 & 375 & 410 & - & 25.8 \\
\hline
\end{tabular}

及び Hoffmann と Petzow ${ }^{12)}$ の報告と一致している.図 5 には， 焼結助剤配合を点線で示し, この状態図から推定される析出結 晶相を併せて表 4 に示した. (1) $\mathrm{Yb} / \mathrm{Si} 1.0$ 配合の $\mathrm{Si}_{3} \mathrm{~N}_{4}$ では, $\mathrm{Yb}_{2} \mathrm{SiO}_{5}$ の析出が予想されるが, 同定された結晶相は $\beta-\mathrm{Si}_{3} \mathrm{~N}_{4}$, $\mathrm{Yb}_{2} \mathrm{Si}_{2} \mathrm{O}_{7}, \mathrm{Yb}_{4} \mathrm{Si}_{2} \mathrm{~N}_{2} \mathrm{O}_{7}$ であった. (2) $\mathrm{Yb} / \mathrm{Si} 0.5$ 配合の $\mathrm{Si}_{3} \mathrm{~N}_{4}$ は, $\mathrm{Yb}_{2} \mathrm{Si}_{2} \mathrm{O}_{7}$ の析出が予想されるが，同定された結晶相は $\beta-\mathrm{Si}_{3} \mathrm{~N}_{4}$ 及 び $\mathrm{Yb}_{4} \mathrm{Si}_{2} \mathrm{~N}_{2} \mathrm{O}_{7}$ であった. (3) $\mathrm{Yb} / \mathrm{Si} 0.4$ 配合の $\mathrm{Si}_{3} \mathrm{~N}_{4}$ は, $\mathrm{Yb}_{2} \mathrm{Si}_{2} \mathrm{O}_{7}$ 及び $\mathrm{Si}_{2} \mathrm{~N}_{2} \mathrm{O}$ の析出が予想されたが，同定された結晶相は $\beta$ $\mathrm{Si}_{3} \mathrm{~N}_{4}$ のみであった。この配合は， $\mathrm{Yb}_{2} \mathrm{O}_{3}-\mathrm{SiO}_{2}$ 系の共晶点とな る配合であり, 共晶点配合のガラスは最も安定であり, 結晶化 速度が遅いために, 結晶化熱処理を行ったにもかかわらず, 結 晶相が析出しなかったものと考えられる. (4) $\mathrm{Yb} / \mathrm{Si} 0.1$ 配合で は, (3)配合と同様に $\mathrm{Yb}_{2} \mathrm{Si}_{2} \mathrm{O}_{7}$ 及び $\mathrm{Si}_{2} \mathrm{~N}_{2} \mathrm{O}$ の析出が予想された が, 同定された結晶相は $\beta-\mathrm{Si}_{3} \mathrm{~N}_{4}$ のみで, 結晶相の弱い回折ピー クは認められたが同定できなかった。今回作製した $\mathrm{Si}_{3} \mathrm{~N}_{4}$ の粒 界に析出する結晶相は状態図から予測されたものとは一致しな い結果となった。これは, 焼結体の粒界での結晶化挙動は複雑 であること, また, 今回作製した $\mathrm{Si}_{3} \mathrm{~N}_{4}$ は比較的焼結助剤添加 量の少ない条件であり，局所的な組成の不均質性等の影響を受 けたこと等によると考えられる，今後は, 詳細な粒界析出相の 同定及び析出形態の解析を行う必要がある.

焼結助剤添加量 10 mass $\%$ の $\mathrm{Si}_{3} \mathrm{~N}_{4}$ で, 同定された結晶相, 高 温強さ特性及び耐酸化性の評価結果をまとめて表 5 に示す。粒 界相に融点が $2153 \mathrm{~K}$ である $\mathrm{Yb}_{4} \mathrm{Si}_{2} \mathrm{~N}_{2} \mathrm{O}_{7}$ が析出している(1)及び (2)の焼結助剂配合の $\mathrm{Si}_{3} \mathrm{~N}_{4}$ が， $1400^{\circ} \mathrm{C}$ で高い曲げ強さを有して いる. $\mathrm{Yb}_{4} \mathrm{Si}_{2} \mathrm{~N}_{2} \mathrm{O}_{7}$ に加えて融点が $2123 \mathrm{~K}$ の $\mathrm{Yb}_{2} \mathrm{Si}_{2} \mathrm{O}_{7}$ が析出し た (1) $\mathrm{Yb} / \mathrm{Si} 1.0$ 配合の $\mathrm{Si}_{3} \mathrm{~N}_{4}$ は, $\mathrm{Yb}_{4} \mathrm{Si}_{2} \mathrm{~N}_{2} \mathrm{O}_{7}$ のみが析出した(2) $\mathrm{Yb} / \mathrm{Si} 0.5$ 配合の $\mathrm{Si}_{3} \mathrm{~N}_{4}$ に比較して高い $1500^{\circ} \mathrm{C}$ 曲げ強さを有し, また，耐酸化性にも優れる結果となった。 (1) Yb/Si 1.0配合と (2) $\mathrm{Yb} / \mathrm{Si} 0.5$ 配合の $\mathrm{Si}_{3} \mathrm{~N}_{4}$ は焼結温度の違いから組織も異なると 考えられるが, 耐酸化性は組織よりも酸素や窒素イオンの拡散 経路となる粒界ガラス相量に依存することから, (1) Yb/Si 1.0配 合の $\mathrm{Si}_{3} \mathrm{~N}_{4}$ の優れた高温特性は, $\mathrm{Yb}_{4} \mathrm{Si}_{2} \mathrm{~N}_{2} \mathrm{O}_{7}$ に加えて $\mathrm{Yb}_{2} \mathrm{Si}_{2} \mathrm{O}_{7}$ の析出により, 残存する粒界ガラス相量が減少したことに起因 すると考えられる. 結晶相の析出が認められない(3), (4)配合の $\mathrm{Si}_{3} \mathrm{~N}_{4}$ は, 高い固相温度となる $\mathrm{Yb}_{2} \mathrm{O}_{3}-\mathrm{SiO}_{2}$ 系焼結助剤を用いた にもかかわらず, $1400^{\circ} \mathrm{C} て ゙$ 曲げ強さが低下した. しかし, (3) $\mathrm{Yb} /$ $\mathrm{Si} 0.4$ 配合の $\mathrm{Si}_{3} \mathrm{~N}_{4}$ の $1500^{\circ} \mathrm{C}$ 強さは $292 \mathrm{MPa}$ と低いが, $1500^{\circ} \mathrm{C}$ 強さ保持率（室温強さ $/ 1500^{\circ} \mathrm{C}$ 強さと定義）は, $80 \%$ であり (1) $\mathrm{Yb} / \mathrm{Si} 1.0$ 配合の $\mathrm{Si}_{3} \mathrm{~N}_{4}$ の值79\% と同程度の值である. (3) $\mathrm{Yb} / \mathrm{Si}$ 0.4配合の $\mathrm{Si}_{3} \mathrm{~N}_{4}$ は $\mathrm{Yb}_{2} \mathrm{O}_{3}-\mathrm{SiO}_{2}$ 系の共晶点配合であることから, 粒界に存在する $\mathrm{Yb}-\mathrm{Si}-\mathrm{O}$ 系ガラスの構造が強固になりガラス 相の粘度も高いと予想され ${ }^{13)}$, 粒界への結晶相の析出がなくて も $1500^{\circ} \mathrm{C}$ 強さ保持率が高くなったものと考えられる．この配合 の $\mathrm{Si}_{3} \mathrm{~N}_{4}$ は室温強さも低く, 焼結条件及び結晶化処理条件の 適正化を図ることにより高温強さ向上の可能性があると考えら れる。 
$\mathrm{Yb}_{2} \mathrm{O}_{3}-\mathrm{SiO}_{2}$ 系焼結助剤を用いたガス圧焼結 $\mathrm{Si}_{3} \mathrm{~N}_{4}$ は, 焼結助 剂配合によっては高温強さに優れるが，室温強さが $500 \mathrm{MPa}$ 程 度であり, $\mathrm{Y}_{2} \mathrm{O}_{3}-\mathrm{Al}_{2} \mathrm{O}_{3}$ 系焼結助剤を用いたガス圧焼結 $\mathrm{Si}_{3} \mathrm{~N}_{4}$ に 比較して低い值である。これは， $\mathrm{Yb}_{2} \mathrm{O}_{3}-\mathrm{SiO}_{2}$ 系の固相温度が 高いことにより焼結性が低下したためと考えられ，さらに焼結 条件の適正化が必要である.

\section{4. 総 括}

無加圧焼結が可能となる液相生成領域の配合とした $\mathrm{Yb}_{2} \mathrm{O}_{3}$ $\mathrm{SiO}_{2}$ 系焼結助剤を用いた $\mathrm{Si}_{3} \mathrm{~N}_{4}$ の高温特性向上のための最適な 焼結助剤条件を検討することを目的として, 焼結助剤の $\mathrm{Yb}_{2} \mathrm{O}_{3} /$ $\mathrm{SiO}_{2}$ モル比を変化させたガス压焼結 $\mathrm{Si}_{3} \mathrm{~N}_{4}$ の高温強さ特性及び 耐酸化特性の評価を行い, 以下の結果を得た.

(1) (1) $\mathrm{Yb} / \mathrm{Si} 1.0$ 配合 $\left(\mathrm{Yb}_{2} \mathrm{O}_{3} / \mathrm{SiO}_{2}\right.$ モル比が 1.0$)$, (2) $\mathrm{Yb} / \mathrm{Si}$ 0.5 配合 $\left(\mathrm{Yb}_{2} \mathrm{O}_{3} / \mathrm{SiO}_{2}\right.$ モル比が 0.5$)$, (3) $\mathrm{Yb} / \mathrm{Si} 0.4$ 配合 $\left(\mathrm{Yb}_{2} \mathrm{O}_{3} /\right.$ $\mathrm{SiO}_{2}$ モル比が 0.408$)$, (4) $\mathrm{Yb} / \mathrm{Si} 0.1$ 配合 $\left(\mathrm{Yb}_{2} \mathrm{O}_{3} / \mathrm{SiO}_{2}\right.$ モル比が $0.163 ） の 4$ 条件の焼結助剤配合で, ガス圧焼結 $\mathrm{Si}_{3} \mathrm{~N}_{4}$ の作製と その高温特性の評価を行った。この結果, (1) Yb/Si 1.0配合, 焼 結助剤添加量 10 mass $\%$ の条件で, 最も高温特性の優れた $\mathrm{Si}_{3} \mathrm{~N}_{4}$ が得られ, その特性は, $1400^{\circ} \mathrm{C}$ 曲げ強さが $510 \mathrm{MPa}, 1500^{\circ} \mathrm{C}$ の曲げ強さが $395 \mathrm{MPa}, 1300^{\circ} \mathrm{C} \times 300 \mathrm{~h}$ の酸化処理後の酸化増 量は $13.2 \mathrm{~g} / \mathrm{m}^{2}$ であった.

(2) $\mathrm{Si}_{3} \mathrm{~N}_{4}$ の生成相を同定した結果, (1) $\mathrm{Yb} / \mathrm{Si} 1.0$ 配合では 粒界相に高融点の $\mathrm{Yb}_{4} \mathrm{Si}_{2} \mathrm{~N}_{2} \mathrm{O}_{7}$ 及び $\mathrm{Yb}_{2} \mathrm{Si}_{2} \mathrm{O}_{7}$ の析出が認められ, これらの結晶相の析出及び結晶相析出による粒界ガラス相の低 減により優れた高温特性が発現したものと考えられる.

(3) (2) $\mathrm{Yb} / \mathrm{Si} 0.4$ 配合は, 室温強さが低いが， $1500^{\circ} \mathrm{C}$ 強さ保 持率が $80 \%$ と高い結果となった。これは，この配合が $\mathrm{Yb}_{2} \mathrm{O}_{3}-$ $\mathrm{SiO}_{2}$ 系の共晶点配合であることから, 粒界の $\mathrm{Yb}-\mathrm{Si}-\mathrm{O}$ 系ガラ スの粘度も高いと予想され，粒界への結晶相の析出がなくても $1500^{\circ} \mathrm{C}$ 強さ保持率が高くなったものと考えられる. 燒結条件及
び結晶化処理条件の適正化を図ることにより高温強さ向上の可 能性があると考えられる.

（4）今後は, 粒界析出相の同定及び存在形態の解析, 及び, $\mathrm{Si}_{3} \mathrm{~N}_{4}$ 粒子形態等の組織観察を行い, ガス圧焼結条件の適正化 を図っていく必要がある。

\section{References}

1) Mitomo, M. and Tajima, Y., J. Ceram. Soc. Japan (Seramikkusu Ronbunshi), Vol. 99, pp. 1014-1025 (1991).

2) Murakami, Y. and Yamamoto, H., J. Ceram. Soc. Japan (Seramikkusu Ronbunshi), Vol. 99, pp. 215-221 (1991) [in Japanese].

3) Murakami, Y. and Yamamoto, H., J. Ceram. Soc. Japan, Vol. 101, pp. 1101-1106 (1993).

4) Toropov, N. A. and Bondar, I. A., Izu. Akad. Nauk SSSR, Otd Khim. Nauk, No. 8, pp. 1372-1372 (1961).

5) Toropov, N. A., Bondar, I. A. and Galakhov, F. A., Trans. Intern. Ceram. Cogr. 8th Copenhagen, pp. 87-87 (1962).

6) Toropov, N. A. and Bondar, I. A., Bull. Acad. Sci. USSR, Div. Chem. Sci., pp. 1280-1280 (1961).

7) Nishimura, T. and Mitomo, M., J. Mater. Res., Vol. 10, pp. 240-242 (1995).

8) Murakami, Y., Akiyama, K. and Yamamoto, H., J. Mater. Sci. Lett., Vol. 15, pp. 1271-1272 (1996).

9) Nishimura, T., Mitomo, M. and Suematsu, H., J. Mater. Res., Vol. 12, pp. 203-209 (1997).

10) Park, H., Kim, H.-E. and Niihara, K., J. Am. Ceram. Soc., Vol. 80, pp. 750-756 (1997).

11) Guo, S., Hirosaki, N., Yamamoto, Y., Nishimura, T. and Mitomo, M., J. Mater. Res., Vol. 16, pp. 3254-3261 (2001).

12) Hoffmann, M. J. and Petzow, G., Mat. Res. Soc. Symp. Proc., Vol. 287, pp. 3-14 (1993).

13) Yamamoto, H., Akiyama, K., Hirata, T. and Murakami, Y., J. Ceram. Soc. Japan, Vol. 113, pp. 154-160 (2005) [in Japanese]. 